Yurii CHENTUKOV

Mariupol State University

DOI : $10.14746 /$ ps.2021.1.5

https://orcid.org/0000-0002-7878-7769

Tetyana MARENA

Mariupol State University

https://orcid.org/0000-0002-7970-4005

Olha ZAKHAROVA

Mariupol State University

https://orcid.org/0000-0002-8718-0205

\title{
DEBT SECURITY OF CEE COUNTRIES: ACTUAL APPROACHES AND METHODS OF EVALUATION
}

\section{INTRODUCTION}

Modern frames of international economic security are primarily determined by the state of the security environment of national economies. The national economic security is a complex multidimensional system, which nowadays is formed in terms of significant expansion and modification of the list of factors that threaten it. In the early 80 's of the twentieth century, aggravation of the debt crisis in some developing countries has drawn the attention of scholars and regulatory institutions to the problems of debt security as an integral part of economic and, in particular, financial security of the state. Given the increasing degree of financial interdependence of national economies in the globalized world and expanding the scale of countries' external financial relations, nowadays the task of debt security ensuring is at the intersection of geoeconomic and geopolitical interests of countries.

Exacerbation of debt problems in many countries (including those related to the growth of the external debt burden) has actualized the search and scientific reasoning the ways to improve regulatory mechanisms for resolving debt problems. An efficient public policy of ensuring the optimal level of debt security (both internal and external) should be based on the results of its current state assessment. The adequacy and informativeness of the obtained results of such assessment largely depends on the choice of approaches and methods of determining the state of the country's debt security. Alongside it, nowadays there are no generally accepted approaches to determining the level of debt security of the country.

The study is aimed at analyzing actual methods and techniques of country's debt security evaluation, developing authors' approach towards estimating the level of debt security based on the calculation of the relevant integral index, and assessing the level of debt security of Central and Eastern European countries on the basis of the proposed tools applying. The subject of the research is the methodical approaches towards eval- 
uating the debt security of CEE countries. The main structure of the article includes four sections, namely "Literature review," which contains an analysis of canonical and recent works on debt security assessment; "Methodology," where the authors' approach to assessing the level of country's debt security is presented; "Results," which contains the results of testing the proposed approach for evaluating the debt security of CEE countries; "Conclusions."

\section{LITERATURE REVIEW}

Nowadays the national level of economic security ensuring is considered to be the basic one. B. Buzan argues the need to expand the theoretical framework of security studies to three levels (international security system, national security and security of the individual), a sovereign state is the most important and effective guarantor of security, and therefore security of the state is a central element of the global security system (Buzan, 1991).

In terms of countries' growing interdependence, national economic security shaping takes place on the background of external factors strengthening, which in particular include the growth of external borrowings and corresponding accumulation of external debt. According to O. Bulatova et al., "integration of the countries of the world into the world economy causes a significant influence of the external sector on the development of national economy" (Bulatova, Trofymenko, Karpenko, Fedorov, 2020: 425). M. Dudin et al. emphasize that external factors are increasingly influencing on the economic security of countries (Dudin, Fedorova, Ploticina, Tokmurzin, Belyaeva, Ilyin, 2018).

The growth of borrowing and the corresponding accumulation of public debt, including external one, is not an evidence of a bad debt security. Government borrowings can appear to be an attractive source of financing growth-enhancing initiatives, especially when investment activity is curtailed. Reasonable growth of government external borrowings can become a source of economic growth for countries suffering from capital deficit. External loans allow a country to invest and consume more than its economy produces, they also can be a substitute for domestic loans, reducing the impact on domestic interest rates and the cost of financing. Medium- and long-term borrowings are often invested in infrastructure projects, which has a positive effect on economic growth. External debt can have additional effects for the technology sector, accelerating research and development and delivering organizational and institutional innovation. However, when a country's debt does not meet certain quantitative criteria and payments for its servicing increase uncontrollably, it becomes destructive, creating a number of risks to the economic system, slowing down economic growth and deteriorating the country's economic security.

The analysis of studies which are devoted to methods of the debt security estimation shows that today the following methodical approaches to assess its level are the most widespread:

- determining the level of debt security based on the assessment of its individual indicators; 
- taking into account some indicators of debt while applying complex methods of assessment of economic or financial security of the state;

- integrated assessment of the debt security level based on the calculation of the integrated security index.

A study of the content of research papers on the assessment of economic security of the state as a whole and its individual components shows that in many countries the concept of debt security of the state is not considered separately. The categories "debt security" (or "debt safety") and "financial security" are often applied to households and businesses (Hrybinenko, Bulatova, Zakharova, 2020). If the concept of debt security is considered in relation to the state, often the assessment of its level is actually equated to a study of the public debt (both internal and external) based on the analysis of a number of absolute and relative indicators (Makarchuk, Perchuk, Yaremenko, 2017; Marena, Peronko, 2019; Redo, 2018). Indicators of debt security are specific statistical indices of the development of the debt situation in the country, which comprehensively characterize the phenomena and trends that occur in the debt sector.

In international practice, a wide range of indicators of indebtedness and liquidity is used, but there is no common system of indicators and their thresholds to determine the level of debt security. According to the international experience, the main criterion for assessing the level of indebtedness is the ratio of public debt to GDP. However, there is no common approach to determining the optimal level of this indicator, and the relationship between public debt and economic growth is still the subject of scientific debate.

The vast majority of studies on the relationship between public debt and economic growth determine the threshold of debt-to-GDP ratio in the range of 60 to 100 percent. The Maastricht criteria set the threshold of the government debt-to-GDP ratio at 60 percent. The experts of the World Bank have found out that countries whose debt-to-GDP ratios exceed 77 percent, as a rule, experience significant slowdowns in economic growth (Caner, Grennes, Koehler-Geib, 2010). C. M. Reinhart and K. S. Rogoff (2010) argue that "the relationship between government debt and real GDP growth is weak for debt/GDP ratios below a threshold of 90 percent of GDP. Above 90 percent, median growth rates fall by 1 percent, and average growth falls considerably more." Some later studies criticized the results obtained by C. M. Reinhart and K. S. Rogoff, in particular, questioned their central claim that excess debt causes recessions (Herndon, Ash, Pollin, 2013). The contradictory results of studies on the relationship between debt and economic growth and the corresponding different views on the threshold of the debt-to-GDP ratio are largely determined by the specific features of the studies, which are based on different country samples, different phases of the economic cycle, time periods and research methodologies.

Other widespread indicators of indebtedness and liquidity include: the ratio of the public debt to the state budget revenues; the ratio of the total amount of annual payments on external debt to the state budget revenues; the ratio of the total amount of annual payments on public debt to GDP; the level of external debt per capita; the ratio of external debt to the annual exports of goods and services; the ratio of international reserves to the volume of gross external debt, etc.

Joint World Bank-IMF Debt Sustainability Framework for Low-Income Countries is based on the following main indicators: present value of external debt in percent of 
GDP and exports; external debt service in percent of export and revenue; present value of total public debt in percent of GDP (Joint World Bank-IMF Debt Sustainability Framework for Low-Income Countries).

B. Bökemeier and A. Stoian (2018) concentrate on countries' fiscal sustainability problems and study debt sustainability in Central and East European countries by means of calculating the stabilized debt ratios, turning points, and debt limits using estimates of a fiscal reaction function, capturing the response of the government to changes in their debt ratio. M. Wysocki studies the sustainability of public debt stock in terms of solvency in CEE countries using Ata Ozkaya's Stepwise Algorithm modified by Zivot-Andrews test to establish the level of integration variables and analyses such indicators as government consolidated gross debt as percentage of GDP, total general government expenditure as percentage of GDP, total general government tax revenue as percentage of GDP, primary budget surplus as percentage of GDP, budget balance as percentage of GDP (Wysocki, 2017).

The importance of debt security to ensure a sufficient overall level of economic security is also confirmed by the inclusion of individual debt indicators in comprehensive methods of assessing the economic or financial security of the state. This practice has become widespread within the methods proposed by Ukrainian scholars (Hrybinenko, Bulatova, Zakharova, 2020; Kharazishvily, 2014; Varnalii, Onyshchenko, 2016). In addition, in the methodology proposed by J. de La Torre and D. Neckar (which was the first attempt to comprehensively study economic security, taking into account the interdependence of internal and external social, economic and political factors) among external economic factors that combine the degree of external constraints on domestic economic policy, external debt is allocated (de La Torre, Neckar, 1988).

Evaluation of country's debt security by analyzing individual indicators of debt is rather a simple approach, which nevertheless has some drawbacks. If the indicators of security show different trends in the debt situation (for instance, some indicators demonstrate an increase in security level and other ones evidence security worsening), it may be rather difficult to define the impact of which indicator will prevail. Furthermore, this technique makes it impossible to provide a comparative analysis of the debt security dynamics for different time periods. Taking into consideration all mentioned facts, the techniques that provide a comprehensive assessment of the level of debt security are considered to be more efficient. Such tools are based on the calculation of the integral index of the debt security and make it possible to analyze the dynamic shifts in the level of country's debt security compared to determined threshold.

Despite all the advantages of integral methods of assessing the level of debt security, they are imperfect, which is manifested in their following shortcomings: different scholars justify different criteria for selecting indicators to be included in the integral index; the ambiguous issue is determining the normative values (threshold) of the debt security indicators; some approaches lack important indicators that can significantly affect the state of debt security (Marena, Peronko, 2019).

Nowadays, methods of assessing debt security based on the calculation of the integral index are mostly widespread in post-Soviet countries. In particular, in Ukraine, the approved technique provides the tools for calculating the integral index of the debt security which is considered to be a component of financial security of the state 
(Pro zatverdzhennia Metodychnykh rekomendatsii shchodo rozrakhunku rivnia ekonomichnoi bezpeky Ukrainy, 2013). The Methodic recommendations for calculating the level of economic security of Ukraine, approved in 2013, define nine components of economic security (including indicators of debt security) and their thresholds. The debt security indicators in Ukraine include: the ratio of public and publicly guaranteed debt to GDP; the ratio of gross external debt to GDP; weighted average yield of government bonds on the primary market; Index EMBI (Emerging Markets Bond Index) + Ukraine; the ratio of official international reserves to gross external debt. The results of previous studies of the authors of the article show that the Ukrainian methodic approach has some shortcomings, in particular, in the context of a set of indicators used as components of debt security index (Marena, Peronko, 2019).

The choice of proper indicators for the list of the debt security components is an important stage in the assessment of debt security. Indicators should be selected taking into account the principles of representativeness, reliability and availability of information; they must most fully characterize the state of indebtedness and solvency, and are to be based on indicators of debt security defined by the international organizations and elaborated by the best international practice. Moreover, given the growth of the national economies' dependence on external creditors, consideration of indicators of external indebtedness among the components of debt security index becomes more and more important. It is especially important to take into account the external debt indicators when calculating the debt security index for those economies where the significant debt denominated in foreign currencies is rather a big problem (this applies, in particular, to CEE countries).

\section{METHODOLOGY}

The authors propose an approach to assessing the level of debt security of country using the methodology of constructing complex (integral) indicators. The proposed methodical approach is practically tested in assessing the level of debt security of CEE countries. Central and Eastern Europe (CEE) is a term used by the OECD for a group of countries including Albania, Bulgaria, Croatia, the Czech Republic, Hungary, Poland, Romania, the Slovak Republic, Slovenia and three Baltic countries (Estonia, Latvia and Lithuania).

Based on the methodical techniques and tools of multidimensional analysis adopted in international practice (Handbook on Constructing Composite Indicators, 2008), a methodical approach to quantitative and qualitative assessment of the level of country's debt security is offered, which involves the following stages:

1. Reasoning the essence and structure of the integral debt security index.

2. Assessment of the debt security indicators' content, their classification, determining their critical values (threshold).

3. Selecting and reasoning the method of standardization of individual parameters of debt security.

4. Selecting and reasoning the form of the integral debt security index (method of indicators' aggregation). 
5. Conducting empirical calculations on a sample of CEE countries, assessing CEE countries' development in terms of their debt security.

The Debt Security Index (DSI) of the state is an integral (complex) assessment of the country's debt security level, which reflects the scope of indebtedness and the state of solvency of the national economy, given the increasing actual dependence of countries on external borrowing. Taking into consideration the requirements of availability, representativeness and informativeness of the country's indebtedness and solvency indicators, it is proposed to include six debt indicators in the DSI.

These indicators include disincentives, the growth of which causes a deterioration in the level of debt security, and stimulants, the increase of which identifies the improvement of the country's debt security. The system of indicators, their essence in terms of their role as an identifier of the security level, the nature of their impact, as well as their thresholds defined by international organizations, are presented in Table 1.

Table 1

Debt security indicators as components of the integral debt security index

\begin{tabular}{|c|c|c|c|}
\hline $\begin{array}{l}\text { Debt indicators } \\
\text { (DI) }\end{array}$ & Description & $\begin{array}{c}\text { Stimulant/ } \\
\text { Disincentive }\end{array}$ & Thresholds \\
\hline $\begin{array}{l}\text { Total Public Debt to GDP Ratio, } \\
\text { percent }\left(\mathrm{DI}_{1}\right)\end{array}$ & $\begin{array}{l}\text { Characterizes the overall level of public } \\
\text { sector debt }\end{array}$ & Disincentive & $60 \%$ \\
\hline $\begin{array}{l}\text { External Debt to GDP Ratio, per- } \\
\text { cent }\left(\mathrm{DI}_{2}\right)\end{array}$ & $\begin{array}{l}\text { Shows the overall level of the debt compo- } \\
\text { nent of the economy }\end{array}$ & Disincentive & $30 \%$ \\
\hline $\begin{array}{l}\text { External Debt to Exports Ratio, } \\
\text { percent }\left(\mathrm{DI}_{3}\right)\end{array}$ & $\begin{array}{l}\text { Demonstrates the relative long-term ability } \\
\text { of the state to accumulate foreign exchange } \\
\text { earnings without additional pressure on the } \\
\text { balance of payments }\end{array}$ & Disincentive & $140 \%$ \\
\hline $\begin{array}{l}\text { External Debt per Capita, US dol- } \\
\text { lars }\left(\mathrm{DI}_{4}\right)\end{array}$ & $\begin{array}{l}\text { The indicator is used in international prac- } \\
\text { tice as one of the main indicators of the } \\
\text { level of external debt. The growth of the } \\
\text { indicator shows an increase in the foreign } \\
\text { debt burden and the deterioration of the } \\
\text { country's financial security. }\end{array}$ & Disincentive & $\begin{array}{l}\text { Up to } \\
200 \text { USD }\end{array}$ \\
\hline $\begin{array}{l}\text { International Reserves to Gross } \\
\text { External Debt Ratio, percent }\left(\mathrm{DI}_{5}\right)\end{array}$ & $\begin{array}{l}\text { Shows whether a country can use its re- } \\
\text { serves (and what part of them) to pay off } \\
\text { external debt }\end{array}$ & Stimulant & Over $20 \%$ \\
\hline $\begin{array}{l}\text { Total Reserves in Months of Im- } \\
\text { ports, months }\left(\mathrm{DI}_{6}\right)\end{array}$ & $\begin{array}{l}\text { Reflects the margin of financial strength of } \\
\text { the state and the level of its international } \\
\text { liquidity }\end{array}$ & Stimulant & $\begin{array}{l}\text { More than } \\
3 \text { months }\end{array}$ \\
\hline
\end{tabular}

Source: Compiled by the authors.

It should also be noted that the presented debt security indicators are relative values (in particular relative values of intensity or level), which in context of a methodological point of view provides an opportunity to compare objects that vary in size and terms of development (different countries in particular).

The standardization of debt security indicators involves bringing them to a comparative form (dimensionless values), which makes it possible to compare multidirectional indicators and to include them in the integral assessment. Within the proposed approach the method of comparison of empirical values with the reference value is used; the thresholds of the indicators are selected as reference value (see Table 1). 
Formulas for calculating standardized estimated values (StDIj) are the following ones:

$$
\begin{gathered}
S t D I_{j}=\frac{D I_{j}}{D I_{T h j}}\left(\text { in case of } D I_{j} \text { is a stimulant }\right) \\
\text { or } S t D I_{j}=\frac{D I_{T h j}}{D I_{j}} \text { or (in case of } D I_{j} \text { is a disincentive) }
\end{gathered}
$$

where $D I_{j}$ - empirical value of the debt indicator $j$;

$D I_{T h j}$ - critical value of the debt indicator $j$.

Regarding the form of the debt security index, in this study linear (additive) aggregation is used, which involves the construction of an integral estimate in the form of a weighted arithmetic mean. The calculation formula is as follows:

$$
D S I_{i}=\sum_{j=1}^{n} S t D I_{j} * \alpha
$$

where $D I_{j}$ - standardized assessment of the debt indicator $j$;

$i$ - a country whose level of debt security is assessed;

$n$ - number of debt indicators;

$\alpha$-weighting factor, $\Sigma \alpha j=1$.

To determine the weighting factors, among the existing methods of weighing (method of equal weights, method of expert estimates, method of principal components, etc.) the method of stochastic factor analysis has been selected. In the frame of it on the basis of a quantitative assessment of correlations a dynamic matrix of weights has been constructed (according to the strength of the relationship between debt indicators and the integral index).

The results of the calculation of weights are presented in Table 2.

Within the framework of the proposed approach, the obtained debt security indices allow: first, to build ratings of CEE countries in terms of the level of debt security and to assess their security positions accordingly; second, to characterize the level of debt security of each country and to determine the security zone.

Table 2

System of dynamic weights of debt security indicators

\begin{tabular}{||c|c|c|c|c|c|c||}
\hline Year & $\begin{array}{c}\text { Total Public } \\
\text { Debt to } \\
\text { GDP Ratio }\end{array}$ & $\begin{array}{c}\text { External } \\
\text { Debt to } \\
\text { GDP Ratio }\end{array}$ & $\begin{array}{c}\text { External } \\
\text { Debt to } \\
\text { Exports Ratio }\end{array}$ & $\begin{array}{c}\text { External } \\
\text { Debt per } \\
\text { Capita }\end{array}$ & $\begin{array}{c}\text { International } \\
\text { Reserves to } \\
\text { Gross External } \\
\text { Debt Ratio }\end{array}$ & $\begin{array}{c}\text { Total } \\
\text { Reserves in } \\
\text { Months of } \\
\text { Imports }\end{array}$ \\
\hline 1 & 2 & 3 & 4 & 5 & 6 & 7 \\
\hline 2007 & 0.38 & 0.13 & 0.13 & 0.13 & 0.13 & 0.13 \\
\hline 2008 & 0.38 & 0.13 & 0.13 & 0.13 & 0.13 & 0.13 \\
\hline 2009 & 0.23 & 0.08 & 0.08 & 0.15 & 0.23 & 0.23 \\
\hline 2010 & 0.27 & 0.09 & 0.09 & 0.18 & 0.18 & 0.18 \\
\hline 2011 & 0.40 & 0.10 & 0.10 & 0.20 & 0.10 & 0.10 \\
\hline 2012 & 0.21 & 0.14 & 0.07 & 0.21 & 0.21 & 0.14 \\
\hline 2013 & 0.27 & 0.13 & 0.07 & 0.20 & 0.20 & 0.13 \\
\hline
\end{tabular}




\begin{tabular}{||c|c|c|c|c|c|c||}
\hline 1 & 2 & 3 & 4 & 5 & 6 & 7 \\
\hline 2014 & 0.19 & 0.19 & 0.13 & 0.19 & 0.19 & 0.13 \\
\hline 2015 & 0.18 & 0.18 & 0.06 & 0.18 & 0.24 & 0.18 \\
\hline 2016 & 0.17 & 0.17 & 0.06 & 0.17 & 0.22 & 0.22 \\
\hline 2017 & 0.19 & 0.19 & 0.06 & 0.13 & 0.25 & 0.19 \\
\hline 2018 & 0.19 & 0.19 & 0.06 & 0.13 & 0.25 & 0.19 \\
\hline 2019 & 0.18 & 0.18 & 0.12 & 0.12 & 0.24 & 0.18 \\
\hline
\end{tabular}

Source: Authors' calculations.

The first task is implemented by constructing a ranked distribution of countries by $D S I_{i}$. The second task involves the need to calculate the average level of the debt security index for each year and the standard deviation as an indicator of variation of the debt security indices values in the sample of countries. The algorithm for determining the level and zone of debt security is presented in Table 3.

Table 3

Algorithm for determining the level of debt security relative to the values of the integrated index

\begin{tabular}{||l|c|c||}
\hline \multicolumn{1}{|c|}{ Security zone } & Debt security level & The value of the debt security index $D S I_{i}$ \\
\hline \multirow{3}{*}{ Secure $\left(D S I_{i}>1\right)$} & High & $D S I_{i}>\overline{D S I}_{i}+\delta_{D S I}$ \\
\cline { 2 - 3 } & Satisfactory & $1<D S I_{i}<\overline{D S I}_{i}+\delta_{D S I}$ \\
\hline \multirow{2}{*}{ Insecure $\left(D S I_{i}<1\right)$} & Unsatisfactory & $\overline{D S I} I_{i}-\delta_{D S I}<D S I_{i}<1$ \\
\cline { 2 - 3 } & Critically low & $D S I_{i}<\overline{D S I}_{i}-\delta_{D S I}$ \\
\hline
\end{tabular}

Thus, the country is in a zone of relative security, provided that the debt security index exceeds 1 . In this case, if the index value is higher than the upper margin of variation (it is determined by adding the standard deviation of the index to its average value), the country is characterized by a high level of debt security compared to other countries in the sample. If the index is below the upper margin of variation, but at the same time it exceeds 1 , then the country is characterized by a satisfactory level of security.

On the contrary, countries demonstrating an index value lower than 1 are in the danger zone (insecure zone). Accordingly, their level of debt security is assessed as unsatisfactory. Provided that the index is below the lower margin of variation (it is determined by subtracting the standard deviation of the index from its average value), the level of country's debt security is critically low compared to other countries of the sample.

The presented algorithm allows both to determine the level of debt security and to classify countries into groups according to the state of debt security.

The statistical data of the survey is represented by the official reports and statistical databases of the International Monetary Fund, the World Bank, the Bank for International Settlements, the World Economic Forum, UNCTAD.

The proposed technique is universal and can be applied to any sample of countries. Alongside it, the list of indicators used in this methodical approach may vary depend- 
ing on the specifics of the country whose debt security level is evaluated, special terms of debt formation (in particular, membership in monetary unions, dependence on IMF loans, etc.), access to appropriate statistics. Therefore, the integral index of debt security can be modified and supplemented with additional indicators of indebtedness and solvency.

\section{RESULTS}

The proposed methodic approach is applied to assess the level of debt security of Central and Eastern European countries. According to the results of authors' previous studies (Bulatova, Chentukov, Marena, Shabelnyk, 2020), the countries of the group are highly differentiated both in terms of overall level of economic development and the state of indebtedness and solvency (Fig. 1).

Based on the processing the official statistics on indicators of indebtedness and solvency of CEE countries using the proposed technique to assessing the level of country's debt security, a rating of CEE countries has been obtained according to the relevant integral assessments (Fig. 2).

Figure 1. GDP and external debt of CEE countries, USD million, 2019

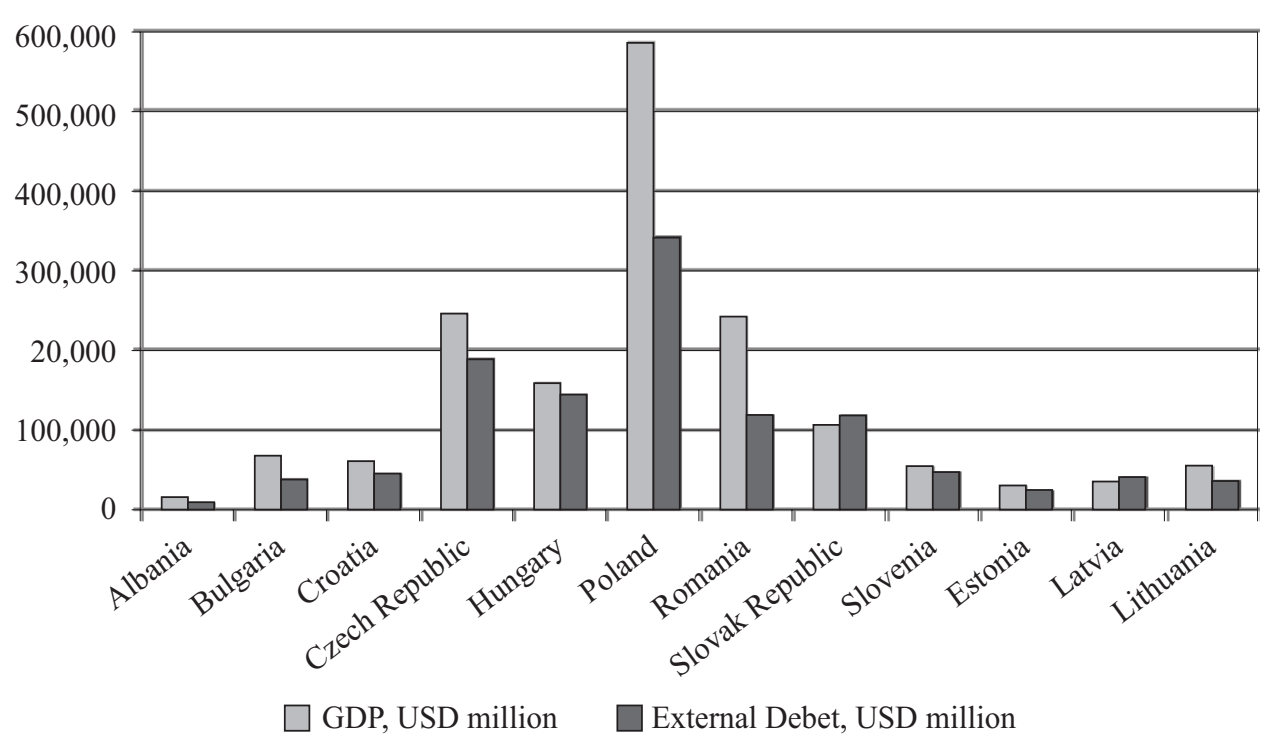

Source: UNCTADstat, World Bank Open Data.

According to the results of calculations, the three countries with the highest level of debt security include Bulgaria (2.1), the Czech Republic (2.03) and Estonia (1.61). Croatia (1.29), Romania (1.21), Poland (1.19) and Albania (1.17) are among the countries with a relatively safe level $(D S I>1)$. Other countries are characterized by a low level of debt security, among which Slovakia (0.53) and Slovenia (0.42) demonstrate 
Figure 2. The integral debt security indices of CEE countries, 2019

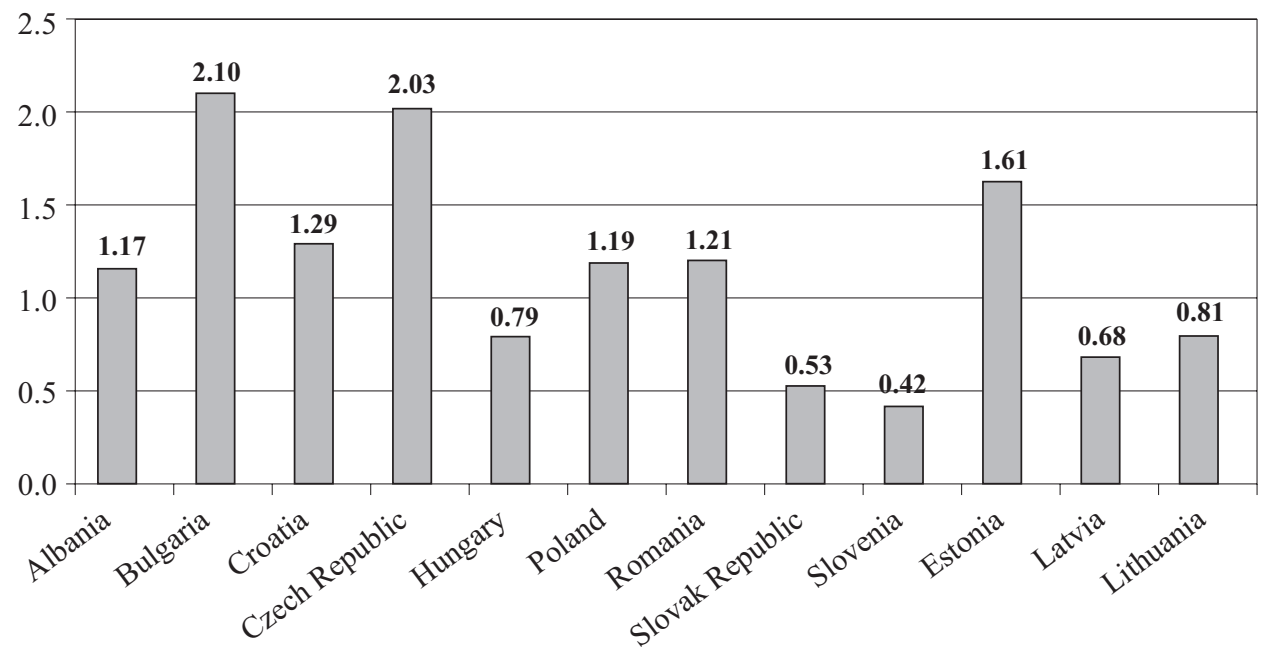

Source: Authors' calculations.

the lowest scores. Slovenia, which is a member of the Eurozone, in addition, in recent years did not comply with the normative value of the public debt to GDP ratio, which according to the Convergence Criteria should not exceed 60\% (in 2019 it was at the level of $66.1 \%$, and in 2013-2018 fluctuated within 70-82\%). It should be noted that among the sample of CEE countries, $58 \%$ ( 7 countries) have a relatively normal level of debt security.

The dynamics of debt security indices of CEE countries are presented in Table 4.

Dynamics of debt security indices of CEE countries for the period of 2007-2019

\begin{tabular}{||l|c|c|c|c|c|c|c|c|c|c|c|c|c||}
\hline \multicolumn{1}{|c|}{ Country } & $\mathbf{2 0 0 7}$ & $\mathbf{2 0 0 8}$ & $\mathbf{2 0 0 9}$ & $\mathbf{2 0 1 0}$ & $\mathbf{2 0 1 1}$ & $\mathbf{2 0 1 2}$ & $\mathbf{2 0 1 3}$ & $\mathbf{2 0 1 4}$ & $\mathbf{2 0 1 5}$ & $\mathbf{2 0 1 6}$ & $\mathbf{2 0 1 7}$ & $\mathbf{2 0 1 8}$ & $\mathbf{2 0 1 9}$ \\
\hline Albania & 1.39 & 1.11 & 1.25 & 1.16 & 0.87 & 0.98 & 0.91 & 0.79 & 1.11 & 1.13 & 1.20 & 1.20 & 1.17 \\
\hline Bulgaria & 2.03 & 2.27 & 2.06 & 1.91 & 2.07 & 1.66 & 1.73 & 1.23 & 1.69 & 1.83 & 2.05 & 2.07 & 2.10 \\
\hline Croatia & 1.10 & 0.99 & 1.09 & 0.95 & 0.77 & 0.83 & 0.89 & 0.78 & 0.99 & 1.05 & 1.19 & 1.22 & 1.29 \\
\hline Czech Republic & 1.60 & 1.44 & 1.35 & 1.19 & 1.08 & 1.03 & 1.11 & 1.08 & 1.33 & 1.57 & 2.08 & 1.92 & 2.03 \\
\hline Hungary & 0.67 & 0.63 & 0.81 & 0.74 & 0.62 & 0.69 & 0.73 & 0.64 & 0.68 & 0.61 & 0.68 & 0.70 & 0.79 \\
\hline Poland & 1.09 & 0.92 & 1.13 & 1.00 & 0.85 & 0.94 & 0.91 & 0.83 & 0.93 & 1.05 & 1.06 & 1.04 & 1.19 \\
\hline Romania & 2.64 & 2.45 & 1.83 & 1.51 & 1.22 & 1.19 & 1.23 & 1.07 & 1.22 & 1.26 & 1.33 & 1.23 & 1.21 \\
\hline Slovak Republic & 1.48 & 1.43 & 0.56 & 0.61 & 0.77 & 0.48 & 0.49 & 0.50 & 0.43 & 0.40 & 0.42 & 0.44 & 0.53 \\
\hline Slovenia & 1.17 & 1.20 & 0.53 & 0.56 & 0.65 & 0.37 & 0.36 & 0.32 & 0.26 & 0.26 & 0.32 & 0.34 & 0.42 \\
\hline Estonia & 6.23 & 5.32 & 2.48 & 2.82 & 4.10 & 1.47 & 1.72 & 1.30 & 1.23 & 1.14 & 1.39 & 1.56 & 1.61 \\
\hline Latvia & 2.96 & 1.49 & 1.17 & 0.96 & 0.83 & 0.80 & 0.86 & 0.53 & 0.59 & 0.58 & 0.67 & 0.66 & 0.68 \\
\hline Lithuania & 1.90 & 1.94 & 1.12 & 0.95 & 1.02 & 0.89 & 0.94 & 0.89 & 0.50 & 0.52 & 0.66 & 0.76 & 0.81 \\
\hline
\end{tabular}

Source: Authors' calculations.

In general, during the period of study, most CEE countries (58\% of the sample) were characterized by an average deterioration in debt security in accordance with the calculated integral indices. In particular, the level of debt security of six coun- 
tries decreased at the highest rate including Estonia (by $10.65 \%$ on average annually for the period of 2007-2019), Latvia (11.52\%), Slovakia (8.3\%), Slovenia (8.26\%), Lithuania (6.88\%), Romania (6.3\%). Among the sample countries, $42 \%$ of economies show a moderate tendency to increase the level of debt security, including the Czech Republic (2.05\% of the average annual growth for the period of 2007-2019), Croatia (1.37\%), Hungary (1.32\%), Poland (0.76\%), Bulgaria ( $0.31 \%)$.

Despite some economic heterogeneity of the CEE region, in most countries in the period 2010-2014 a decrease in the level of debt security was observed. The consequences of the global economic crisis for the financial sectors of these countries have been compounded by the effects of the European debt crisis. Although CEE countries were not at the epicenter of the European crisis (it has developed in such Eurozone economies as Greece, Ireland, Italy, Spain and Portugal), however, the crisis has spread to other EU countries outside the euro area. In more detail, general trends in debt security of the CEE countries, challenges and threats to the debt security of national economies and CEE region have been analyzed in other studies of the authors (Chentukov, Marena, Zakharova, 2021).

It should be noted that there is no general pattern of shifts in the level of debt security, which is confirmed by the calculations of the average annual growth rate of indices (at 5-year intervals, Table 5).

Table 5

Average annual growth rates of debt security indices of CEE countries, \%

\begin{tabular}{||l|c|c|c|c|}
\hline \hline \multicolumn{1}{|c|}{ Country } & $\mathbf{2 0 0 7 - 2 0 1 1}$ & $\mathbf{2 0 1 1 - 2 0 1 5}$ & $\mathbf{2 0 1 5 - 2 0 1 9}$ & $\mathbf{2 0 0 7 - 2 0 1 9}$ \\
\hline Albania & -10.90 & 6.15 & 1.26 & -1.43 \\
\hline Bulgaria & 0.55 & -4.98 & 5.65 & 0.31 \\
\hline Croatia & -8.35 & 6.30 & 6.93 & 1.37 \\
\hline Czech Republic & -9.31 & 5.38 & 11.20 & 2.05 \\
\hline Hungary & -1.93 & 2.17 & 3.81 & 1.32 \\
\hline Poland & -6.04 & 2.46 & 6.25 & 0.76 \\
\hline Romania & -17.55 & -0.05 & -0.18 & -6.30 \\
\hline Slovak Republic & -15.11 & -13.73 & 5.31 & -8.30 \\
\hline Slovenia & -13.64 & -20.12 & 11.93 & -8.26 \\
\hline Estonia & -9.96 & -26.04 & 7.11 & -10.65 \\
\hline Latvia & -27.22 & -8.09 & 3.56 & -11.52 \\
\hline Lithuania & -14.38 & -16.55 & 13.03 & -6.88 \\
\hline
\end{tabular}

Source: Authors' calculations.

Thus, for all countries by the indicated periods there is a diverse change in the level of security. The period of 2007-2012 for all countries except Bulgaria is characterized by negative dynamics of deterioration of debt security (the highest rates are in Latvia, Romania, Slovakia, Slovenia and Lithuania), and the period of 2015-2019, on the contrary, demonstrates a positive trend of increasing the level of security for all countries except Romania (the highest rates in Lithuania, the Czech Republic and Slovenia).

Table 6 presents the dynamics of rating positions of countries in terms of debt security. 
Table 6

Dynamics of security positions rating of CEE countries according to the debt security index for the period of 2007-2019

\begin{tabular}{||l|r|r|r|r|r|r|r|r|r|r|r|r|r|r|r||}
\hline \multicolumn{1}{|c|}{ Country } & $\mathbf{2 0 0 7}$ & $\mathbf{2 0 0 8}$ & $\mathbf{2 0 0 9}$ & $\mathbf{2 0 1 0}$ & $\mathbf{2 0 1 1}$ & $\mathbf{2 0 1 2}$ & $\mathbf{2 0 1 3}$ & $\mathbf{2 0 1 4}$ & $\mathbf{2 0 1 5}$ & $\mathbf{2 0 1 6}$ & $\mathbf{2 0 1 7}$ & $\mathbf{2 0 1 8}$ & $\mathbf{2 0 1 9}$ \\
\hline Albania & 8 & 9 & 5 & 5 & 6 & 5 & 7 & 7 & 5 & 5 & 5 & 6 & 7 \\
\hline Bulgaria & 4 & 3 & 2 & 2 & 2 & 1 & 1 & 2 & 1 & 1 & 2 & 1 & 1 \\
\hline Croatia & 10 & 10 & 9 & 9 & 9 & 8 & 8 & 8 & 6 & 6 & 6 & 5 & 4 \\
\hline Czech Republic & 6 & 6 & 4 & 4 & 4 & 4 & 4 & 3 & 2 & 2 & 1 & 2 & 2 \\
\hline Hungary & 12 & 12 & 10 & 10 & 12 & 10 & 10 & 9 & 8 & 8 & 8 & 9 & 9 \\
\hline Poland & 11 & 11 & 7 & 6 & 7 & 6 & 6 & 6 & 7 & 7 & 7 & 7 & 6 \\
\hline Romania & 3 & 2 & 3 & 3 & 3 & 3 & 3 & 4 & 4 & 3 & 4 & 4 & 5 \\
\hline Slovak Republic & 7 & 7 & 11 & 11 & 10 & 11 & 11 & 11 & 11 & 11 & 11 & 11 & 11 \\
\hline Slovenia & 9 & 8 & 12 & 12 & 11 & 12 & 12 & 12 & 12 & 12 & 12 & 12 & 12 \\
\hline Estonia & 1 & 1 & 1 & 1 & 1 & 2 & 2 & 1 & 3 & 4 & 3 & 3 & 3 \\
\hline Latvia & 2 & 5 & 6 & 7 & 8 & 9 & 9 & 10 & 9 & 9 & 9 & 10 & 10 \\
\hline Lithuania & 5 & 4 & 8 & 8 & 5 & 7 & 5 & 5 & 10 & 10 & 10 & 8 & 8 \\
\hline
\end{tabular}

Source: Authors' calculations.

Among the countries that have improved their security positions in the ranking of 2019 the three leading countries should be specified, namely Bulgaria (from 4 in 2007 to 1 in 2019), the Czech Republic (from 6 in 2007 to 2 in 2019), Croatia (from 10 in 2007 to 4 in 2019), as well as Poland (from 11 in 2007 to 6 in 2019), Hungary (from 12 in 2007 to 9 in 2019). Countries whose security positions have deteriorated, but which at the same time have maintained a relatively high level of debt security, include Estonia (from 1 in 2007 to 3 in 2019) and Romania (from 3 in 2007 to 5 in 2019). The countries having the lowest scores show a decrease in security positions in terms of the integral level of debt security, namely Lithuania (from 5 in 2007 to 8 in 2019), Latvia (from 2 in 2007 to 10 in 2019), Slovakia (from 7 in 2007 to 10 in 2019) and Slovenia (from 9 in 2007 to 12 in 2019).

The application of the proposed integral index of debt security allowed to classify countries into groups depending on the level of debt security (Table 7).

Table 7

The results of the CEE countries grouping by the level of debt security (on the basis of the integral debt security index)

\begin{tabular}{|c|c|c|c|c|c|c|c|c|c|c|c|c|c|}
\hline$\overline{\text { Country }}$ & 2007 & 2008 & 2009 & 2010 & 2011 & 2012 & 2013 & 2014 & 2015 & 2016 & 2017 & 2018 & 2019 \\
\hline Albania & 2 & 2 & 2 & 2 & 3 & 3 & 3 & 3 & 2 & 2 & 2 & 2 & 2 \\
\hline Bulgaria & 2 & 2 & 1 & 1 & 1 & 1 & 1 & 1 & 1 & 1 & 1 & 1 & 1 \\
\hline Croatia & 2 & 3 & 2 & 3 & 3 & 3 & 3 & 3 & 3 & 2 & 2 & 2 & 2 \\
\hline Czech Republic & 2 & 2 & 2 & 2 & 2 & 2 & 2 & 2 & 2 & 1 & 1 & 1 & 1 \\
\hline Hungary & 3 & 3 & 3 & 3 & 3 & 3 & 3 & 3 & 3 & 3 & 3 & 3 & 3 \\
\hline Poland & 2 & 3 & 2 & 3 & 3 & 3 & 3 & 3 & 3 & 2 & 2 & 2 & 2 \\
\hline Romania & 2 & 2 & 1 & 2 & 2 & 2 & 2 & 2 & 2 & 2 & 2 & 2 & 2 \\
\hline Slovak Republic & 2 & 2 & 4 & 3 & 3 & 4 & 4 & 4 & 4 & 4 & 4 & 4 & 4 \\
\hline Slovenia & 2 & 2 & 4 & 4 & 3 & 4 & 4 & 4 & 4 & 4 & 4 & 4 & 4 \\
\hline Estonia & 1 & 1 & 1 & 1 & 1 & 1 & 1 & 1 & 2 & 2 & 2 & 2 & 2 \\
\hline Latvia & 1 & 2 & 2 & 3 & 3 & 3 & 3 & 3 & 3 & 3 & 3 & 3 & 3 \\
\hline Lithuania & 1 & 2 & 2 & 3 & 2 & 3 & 3 & 3 & 3 & 3 & 3 & 3 & 3 \\
\hline
\end{tabular}

Note: 1 - high, 2 - satisfactory, 3 - unsatisfactory, 4 - critically low; 1, 2-secure zone; 3, 4-insecure zone. 
Six countries (Bulgaria since 2009, the Czech Republic since 2016, Romania in 2009, Estonia until 2015, Latvia and Lithuania in 2007) are characterized by a high level of debt security. Ten countries (Albania in 2007-2010, 2015-2019, Croatia in 2007, 2009, 2016-2019, Czech Republic until 2015, Poland in 2007, 2009, 20162019, Romania since 2010, Slovakia and Slovenia in 2007-2008, Estonia since 2015, Latvia in 2008-2009, Lithuania in 2008-2009 and 2011) were in a relative secure zone with a satisfactory level of debt security. Regarding the insecure zones, seven countries are characterized by the unsatisfactory level (Hungary throughout the analyzed period, Latvia since 2010, Lithuania since 2012, Croatia and Poland in 2008, 2010-2015, Slovakia in 2010-2011, Slovenia in 2011). Slovakia and Slovenia are the only countries that have a critically low level of debt security in some years.

The results of countries grouping by the debt security levels are presented in Fig. 3. According to these results, in 2007 92\% (11 countries) and in 2008-2009 83\% (10 countries) were in the secure zone. However, over time the situation worsened: in 2012-2014 only 33\% (4 countries) and in 2016-2019 only 58\% (7 countries) were in the secure zone.

Figure 3. Grouping of countries by level of debt security (number of countries in the group)

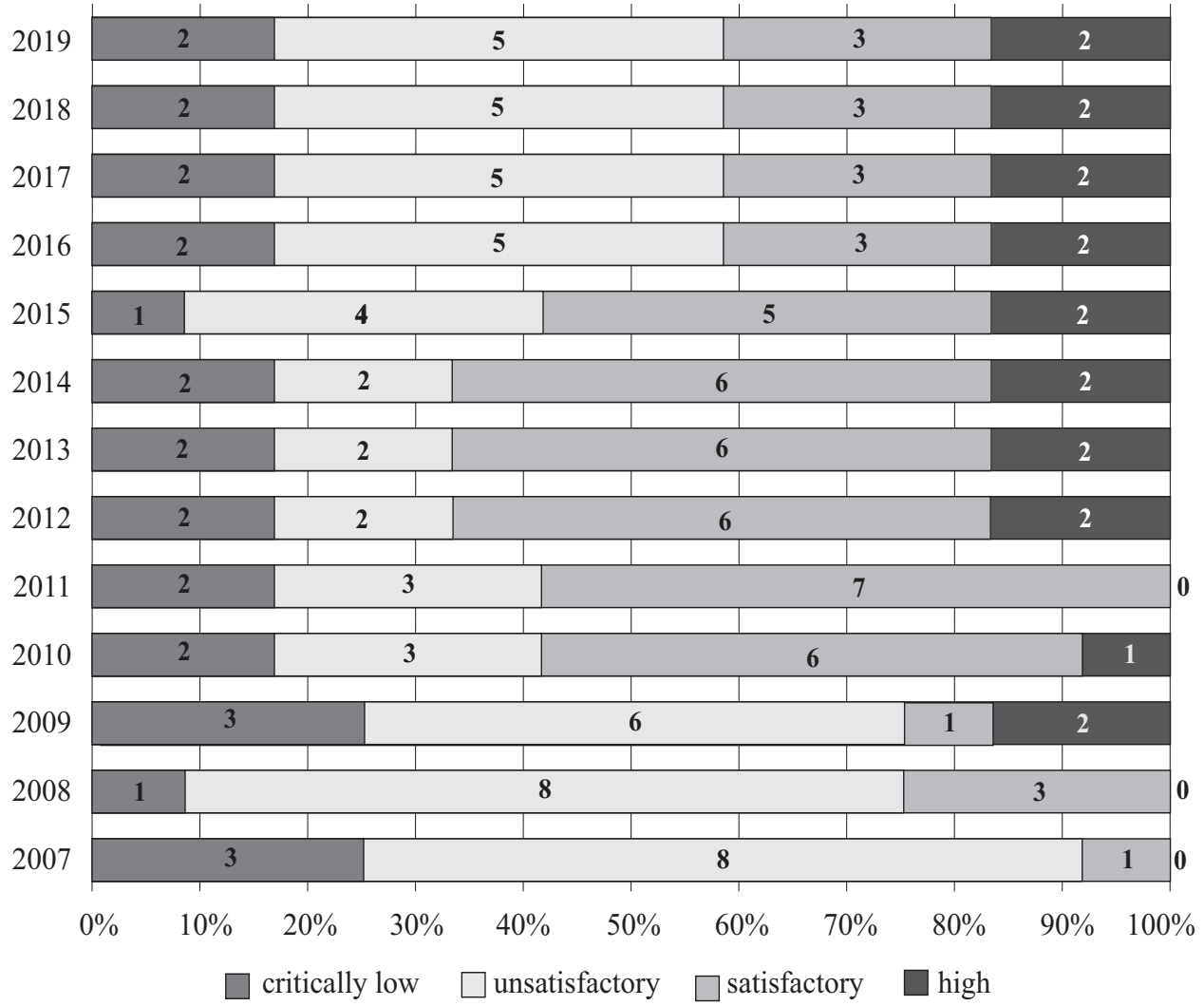

Source: Compiled by the authors. 
Thus, one can state the tendency of weakening the debt security in 2010-2015 and its strengthening to the more proper level in 2016-2019. Factors that in some way can mitigate the risks of significant external debt burden and deterioration of debt security in the CEE countries is the prevalence of stable foreign direct investment and the long maturity of public external debt (Zorell, 2017: 2). Alongside it, the situation with the debt security strengthening in the region can turn out to be rather volatile. Given the current state of global transformations (both in geoeconomic and geopolitical area), exogenous challenges can aggravate in the near future, threatening the financial sectors and debt sustainability of the CEE countries (Marena, 2020). A significant contemporary challenge to the debt security of the Central and Eastern European countries lies in the growth of expenditures on health care due to the COVID-19 pandemic and corresponding increased pressure on the public budgets.

\section{CONCLUSIONS}

Within actual international practice, differentiated approaches are used to assess the level of debt security as an important component of national security. Comprehensive assessment of the state of indebtedness and solvency of the national economy is provided by application of the methods based on the calculation of integral indices that reflect the dynamic changes in the level of debt security compared to the thresholds. A method of calculating the integral debt security index of the country is proposed, taking into consideration the requirements of availability, representativeness and informativeness of the country's indebtedness and solvency indicators, generally accepted thresholds of security indicators and the contemporary trend of countries' increasing dependence on external borrowing.

The proposed approach is tested for calculation of the integral debt security indices of the Central and Eastern European countries. The rating of CEE countries on the integral index of debt security is presented. It is determined that the group of CEE countries is differentiated by the state of indebtedness and solvency: the highest level of debt security is demonstrated by Bulgaria, the Czech Republic and Estonia, the lowest one - by Slovakia and Slovenia. Based on the analysis of the dynamics of integral debt security indices for 2007-2019, the rating of countries' security positions, the grouping of CEE countries by the level and zones of debt security, the trends of deterioration of the region's debt security in 2010-2014 (due to the impact of the global economic crisis and the European debt crisis) and its improvement in 2016-2019 has been found out.

Given the universality of the proposed approach, it can be used to calculate debt security indices and to provide comparative studies of the debt sector of any country and region of the world, as well as to identify weaknesses in debt security that is critically important for reasoning the public policy measures to ensure a proper level of debt security. At the same time, the integral index of debt security can be modified and supplemented with additional indicators of indebtedness and solvency taking into consideration the specifics of the country whose debt security level is evaluated, special terms of debt formation, availability of appropriate statistics. 


\section{REFERENCES}

Bökemeier B., Stoian A. (2018), Debt Sustainability Issues in Central and Eastern European Countries, "Eastern European Economics", Vol. 56, No. 5.

Bulatova O., Chentukov Y., Marena T., Shabelnyk T. (2020), The impact of global financial transformations on the economic security of Central and Eastern European countries, "Public and Municipal Finance", Vol. 9, No. 1.

Bulatova O., Trofymenko M., Karpenko O., Fedorov E. (2020), The external component of national economic security, "Przegląd Strategiczny", Issue 13.

Buzan B. (1991), People, States \& Fear: An Agenda for International Security Studies in the PostCold War Era, Pearson Longman, London.

Caner M., Grennes T., Koehler-Geib F., Koehler-Geib F. (2010), Finding the Tipping Point - When Sovereign Debt Turns Bad, Policy Research Working Paper, Vol. 1.

Chentukov Y., Marena T., Zakharova O. (2021), Challenges and threats to the debt security of Central and Eastern European countries, "Środkowoeuropejskie Studia Polityczne”, Vol. 2.

De la Torre J., Neckar D. H. (1988), Forecasting political risks for international operations, "International Journal of Forecasting", Vol. 4, Issue 2.

Dudin M. N., Fedorova I. J., Ploticina L. A., Tokmurzin T. M., Belyaeva M. V., Ilyin A. B. (2018), International practices to improve economic security, "European Research Studies Journal", Vol. 21, Issue 1.

Handbook on Constructing Composite Indicators: Methodology and user guide (2008), OECD, https://www.oecd.org/sdd/42495745.pdf.

Herndon T., Ash M., Pollin R. (2013), Does High Public Debt Consistently Stifle Economic Growth? A Critique of Reinhart and Rogoff, Workingpaper Series, No. 322.

Hrybinenko O., Bulatova O., Zakharova O. (2020), Financial indicators in the system of economic security of the world countries, "Business and Management 2020": 11 th International Scientific Conference, May 7-8, 2020, Vilnius, Lithuania.

Joint World Bank-IMF Debt Sustainability Framework for Low-Income Countries, https://www. imf.org/en/About/Factsheets/Sheets/2016/08/01/16/39/Debt-Sustainability-Framework-forLow-Income-Countries.

Kharazishvili Y. (2014), Methodological approaches to economic security evaluation, "Nauka ta naukoznavstvo", Vol. 4.

Makarchuk I., Perchuk O., Yaremenko L. (2017), Modern state and ways of improving debt safety of Ukraine, "Finansovo-kredytna diialnist: problemy teorii ta praktyky", Vol. 2.

Marena T. (2020), Poland's Financial Sector Development in Terms of Global Financial Transformations, "Research Papers in Economics and Finance", Poznań University of Economics and Business, Issue 3.

Marena T. V., Peronko A. M. (2019), Development of Scientific and Methodical Approaches to the Assessment of the Debt Security of Ukraine, "Bulletin of Mariupol State University. Series: Economics", Vol. 18.

Pro zatverdzhennia Metodychnykh rekomendatsii shchodo rozrakhunku rivnia ekonomichnoi bezpeky Ukrainy: Nakaz Ministerstva ekonomichnoho rozvytku i torhivli Ukrainy vid 29 zhovtnia 2013 r. № 1277, https://zakon.rada.gov.ua/rada/show/v1277731-13.

Redo M. (2018), Comparison of external exposure of Central and Eastern-European states as a factor threatening financial security of their economies, "Historia i Polityka", Vol. 24. 
Reinhart C. M., Rogoff K. S. (2010), Growth in a Time of Debt, "American Economic Review", Vol. 100(2).

UNCTADstat, https://unctadstat.unctad.org/EN/.

Varnalii Z., Onyshchenko S. (2016), Suchasni tendentsii strukturnykh skladovykh finansovoi bezpeky Ukrainy v umovakh hlobalnykh peretvoren, "Formuvannia rynkovoi ekonomiky v Ukraini", Vol. 35, No. 1.

World Bank Open Data, World Bank Group, https://data.worldbank.org/.

Wysocki M. (2017), Sustainability of public debt stock in transition economies in Central and Eastern Europe countries in terms of solvency, "Economic Studies", No. 1 (XCII).

Zorell N. (2017), Large net foreign liabilities of euro area countries: Risks, prospects and policy options, ECB Occasional Paper Series, No. 198, https:/www.ecb.europa.eu/pub/pdf/scpops/ ecb.op198.en.pdf.

\begin{abstract}
The study is aimed at analyzing methods of country's debt security evaluation, developing methodic approach towards estimating the level of debt security based on the calculation of the integral index, and assessing the level of debt security of CEE countries on the basis of the proposed approach. A method of calculating the integral debt security index of the country is developed, taking into account generally accepted thresholds of indebtedness and solvency indicators and the trend of countries' increasing dependence on external borrowing.

The proposed approach is practically tested in assessing the level of debt security of CEE countries. It is determined that the group of CEE countries is differentiated by the state of indebtedness and solvency. The highest level of debt security is demonstrated by Bulgaria, the Czech Republic and Estonia, the worst situation with the debt security is formed in Slovakia and Slovenia. Based on the analysis of the dynamics of integral debt security indices for 2007-2019, the grouping of CEE countries by the level and zones of debt security, the trends of deterioration of the region's debt security in 2010-2015 and its improvement in 2016-2019 has been found out. The proposed approach is universal one; it can be used to calculate debt security indices and to provide comparative studies of the debt sector of any country or region. It can also help to identify weaknesses in country's debt security that is critically important for reasoning the public policy measures to ensure a proper level of debt security.
\end{abstract}

Keywords: debt security, integral index, indebtedness, solvency, public debt, external debt

\title{
ZABEZPIECZENIE DLUŻNE W KRAJACH EUROPY ŚRODKOWEJ I WSCHODNIEJ - WSPÓLCZESNE PODEJŚCIA BADAWCZE ORAZ METODY OCENY
}

\section{STRESZCZENIE}

Celem badania jest analiza metod wyceny papierów dłużnych danego państwa, wypracowanie metodycznego podejścia do szacowania poziomu zabezpieczenia długu w oparciu o wyliczenie wskaźnika integralnego oraz ocena poziomu zabezpieczenia długu państw regionu Europy Środkowo-Wschodniej na podstawie zaproponowanego podejścia. Do badań wykorzystana jest metoda obliczania integralnego indeksu dłużnych papierów wartościowych kraju, 
uwzględniająca ogólnie przyjęte progi wskaźników zadłużenia i wypłacalności oraz tendencję rosnącego uzależnienia państw od pożyczek zewnętrznych.

Proponowane podejście jest praktycznie testowane w ocenie poziomu bezpieczeństwa zadłużenia krajów EŚW. Określa się, że grupę państw EŚW różnicuje stan zadłużenia i wypłacalność. Najwyższy poziom zabezpieczenia dłużnego wykazują Bułgaria, Czechy i Estonia, najgorsza sytuacja z zabezpieczeniami dłużnymi kształtuje się na Słowacji i Słowenii. Na podstawie analizy dynamiki integralnych indeksów dłużnych papierów wartościowych w latach 2007-2019, pogrupowania krajów EŚW według poziomu i stref bezpieczeństwa długu wykryto tendencję pogarszania się bezpieczeństwa dłużnego regionu w latach 2010-2015 oraz jego poprawy w latach 2016-2019. Proponowane podejście jest uniwersalne; może być używane do obliczania indeksów papierów dłużnych oraz do dostarczania badań porównawczych sektora długu dowolnego kraju lub regionu. Zaproponowane badanie może również pomóc w zidentyfikowaniu słabych punktów bezpieczeństwa długu kraju, które są niezwykle ważne dla uzasadnienia środków polityki publicznej w celu zapewnienia odpowiedniego poziomu bezpieczeństwa długu.

Słowa kluczowe: papier dłużny, wskaźnik integralny, zadłużenie, wypłacalność, dług publiczny, dług zewnętrzny 
